\title{
Potential of Omega-3 Supplementation on Muscle Mass, Muscle Strength, and Physical Performance in Elderly Community
}

\author{
Nur Riviati ${ }^{1}$, Taufik Indrajaya ${ }^{1 *}$, Erial Bahar ${ }^{2}$, Dobi Saputra Burni ${ }^{1}$ \\ ${ }^{1}$ Department of Internal Medicine, Faculty of Medicine, Universitas Sriwijaya, Palembang, Indonesia; ${ }^{2}$ Department of Anatomy, \\ Faculty of Medicine, Universitas Sriwijaya, Palembang, Indonesia
}

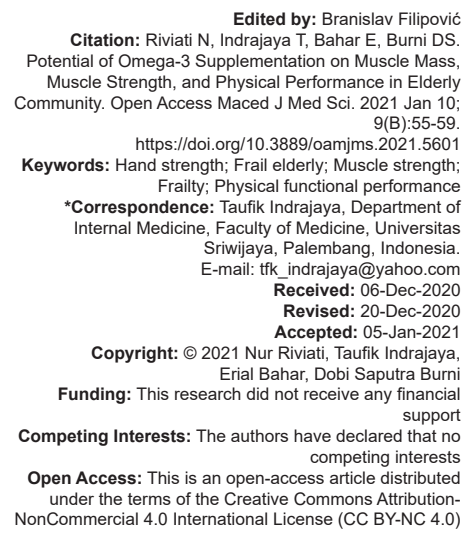

Edited by: Branislav Filipovic
Cic Citation: Riviati N, Indrajaya T, Bahar E, Burni DS. Muscle Strength, and Physical Performance in Elderly
Mustial Muscle Strength, and Physical Performance in Elderly
Community. Open Access Maced J Med Sci. 2021 Jan 10;
9(B):55-59. https://doi.org/10.3889/oamjms.2021.5601 Keywords: Hand strength; Frail elderly; Muscle strength; Frailty; Physical functional performance Frailty; Physical functional performance
$*$ *Correspondence: Taufik Indrajaya, Department of Internal Medicine, Faculty of Medicine, Universitas Sriwijaya, Palembang, Indonesia. E-mail: ttk_indrajaya@yahoo.com Received: 06-Dec-2020 Revised: 20-Dec-2020 Accepted: 05-Jan-202 Copyright: ๑ 2021 Nur Riviati, Taufik Indrajaya, Funding: This research did not receive any financial Competing Interests: The authors have declared that no Open Access: This is an open-access article distribute under the terms of the Creative Commons AttributionNonCommercial 4.0 International License (CC BY-NC 4.0)

\begin{abstract}
BACKGROUND: Geriatric problem characterized by reduced functional ability and impaired adaptation function caused by the decline in various body systems, as well as increased vulnerability to various kinds of stressors, which reduce a person's functional performance.

AIM: This study was aimed to explore the effect of omega-3 supplementation on muscle mass, muscle strength, and physical performance in the elderly community in Palembang, Indonesia.

METHODS: This study is an open clinical trial, to assess the potential of omega- 3 supplementation on muscle mass handgrip strength, and physical activity of elderly community. Omega-3 is given as much as $1.2 \mathrm{~g}$ once a day fo 12 weeks orally. Muscle strength was assessed using Bioelectrical Impedance Analysis. Meanwhile, the muscle strength was assessed with a muscle dynamometer.

RESULTS: Omega-3 supplementation has only shown potent efficacy in improving muscle strength in geriatrics patients (before omega-3 supplementation $25.1+5.11$; after omega-3 supplementation $26.2+5.16$; $p<0.05$ ) Omega 3 supplementation did not show significant improvement in muscle mass and gait ability in elderly patients.

CONCLUSIONS: Omega-3 supplementation improves handgrip strength but does not increase muscle mass and physical performance for geriatrics.
\end{abstract}

\section{Introduction}

The process of ageing is physiological, but the onset, rate of speed and the extent to which the progression of ageing at the level of cells, tissues, organs, and systems is very heterogeneous because it is influenced by genetic and environmental factors [1]. The ageing process can achieve successful ageing (there is no pathological condition and any defects), usual/normal ageing (there is a disease or decreased physiological reserve capacity which is often interpreted as a result of age), and pathologic ageing (there is a severe chronic disease or severe impairment that requires assistance/dependence on other people to carry out activities of daily living). Therefore, the ageing process is associated with an increased risk of vulnerability [1], [2]. Frailty syndrome (FS) is a geriatric problem characterized by reduced functional ability and impaired adaptation function caused by the decline in various body systems, as well as increased vulnerability to various kinds of stressors, which reduce a person's functional performance [1], [2]. The incidence of FS is around $7 \%$ at the age above 65 years and $30 \%$ at the age above 80 years. In a study of Caucasians, women suffer from FS more than men (7:5), whereas, in African Americans, it is twice as common as Caucasians (14:7) [3], [4], [5]. Pathophysiologically, FS is a process of decreasing multi-system ability due to dysregulation by the ageing process, which begins with physiological changes due to age, disease, lack of activity, and inadequate nutritional intake [3], [4], [5], [6], [7], [8], [9].

Specific nutrients such as leucine, Vitamin D, and omega 3 show a role in the skeletal muscle system and have been the latest object of research, either as a single supplement or in combination [10], [11]. Omega 3 is proven to stimulate skeletal muscle protein synthesis [12]. Omega-3 is an essential fatty acid derived from $\alpha$ linolenic acid synthesis which is metabolized into the form of eicosapentaenoic acid, and docosahexaenoic acid has been shown to act as an anti-inflammatory and in the development and maintenance of neurocerebral function [12], [13]. Omega-3 has an anabolic role in skeletal muscle, reduces pro-inflammatory cytokines, and increases insulin sensitivity [14]. Omega-3 also stimulates skeletal muscle protein synthesis by increasing transcription 
and expression of the p70SK gene through the mTOR pathway and inhibiting mitochondrial breakdown by reducing reactive oxygen species (ROS) [15], [16].

FS prevention in the elderly is essential because it can improve the quality of life. FS prevention in old age is crucial because it can enhance the quality of life. However, studies on nutritional intake as prevention in this disorder have contradictory results. This study was aimed to explore the effect of omega-3 supplementation on muscle mass, handgrip strength, and physical performance in the elderly community in Palembang, Indonesia.

\section{Methods}

This study is an open clinical trial, to assess the potential of omega-3 supplementation on muscle mass, handgrip strength, and physical activity of geriatric patients. The inclusion criteria was participants are patients over 60 years of age who have been assessed by a geriatric specialist with FS (based on the clinical criteria of Fried et al., namely if there are three or more of the criteria consisting of weakness, reduced walking speed, decreased physical activity, and weight loss) [3] and had agreed to participate in this study.

The exclusion criteria were that the research subjects were regularly taking anti-inflammatory drugs both steroids and non-steroid, anti-platelet aggregation, anti-coagulants, omega-3 supplementation, consumption of fish oil, and foods rich in omega-3 such as consumption of deep-sea fish (such as tuna fish more than $100 \mathrm{~g} /$ day, salmon fish more than 100 g/day, walnuts more than 200 g/day, mackerel fish more than $100 \mathrm{~g} /$ day, milk more than $500 \mathrm{ml} /$ day, and beef more than $100 \mathrm{~g} /$ day) [17] and Vitamin $\mathrm{D}$ at least 1 month before the study. Furthermore, the research subjects used implanted devices (such as knee or hip endoprosthesis, pacemakers, and walking sticks), history of blood vomiting, bloody/black bowel movements, hemorrhagic stroke, decompensated hypertension heart disease, decompensated coronary artery disease, cancer with or without chemotherapy or radiotherapy, and malnutrition. The drop out criteria were participants who dropped out of drugs for more than 1 day, passed away, suffered from hypersensitivity reactions or drugs side effects such as gastrointestinal bleeding so that the drug administration should be stopped. As many as 40 subjects participated in this study, besides this study has received the approval of the ethics committee of Faculty of Medicine, Universitas Sriwijaya (No. 129/kptfkunsrirsmh/2019).

Omega-3 is given as much as $1.2 \mathrm{~g}$ once a day for 12 weeks orally. Muscle strength was evaluated using Bioelectrical Impedance Analysis (Omron, Singapore). Meanwhile, the muscle strength was assessed with a muscle dynamometer (Kern, Singapore). Physical performance was measured by walking speed evaluation (how long it takes to walk $6 \mathrm{~m}$ long). Data management and analysis were performed using SPSS version 20.0 for Windows with a significance limit of $p<0.05$ with a paired t-test for numerical scale variables. If there is a possibility of a vast difference between before and after treatment, then an interim analysis can be performed.

\section{Results}

Based on gender, seven subjects were male and 33 female with a mean age of $66.325( \pm 4.87)$ years. The last education research subjects were eight high schools and 32 universities. As for comorbid diseases, it was found $30 \%$ and $70 \%$ absent in the study subjects. The research subjects had a mean body mass index of $22.0158( \pm 3.46) \mathrm{kg} / \mathrm{m}^{2}$ (Table 1).

Table 1. Characteristics of participants

\begin{tabular}{llll}
\hline Characteristics & $\mathrm{n}(\%)$ & Mean $( \pm$ SD) & Median (min-max) \\
\hline Age (years) & & & \\
60-65 years old & $21(52.5)$ & $66.325( \pm 4.87)$ & $65(61.00-80.00)$ \\
$66-70$ years old & $12(30.0)$ & & \\
$\quad>71$ years old & $7(17.50)$ & & \\
Gender & & & \\
$\quad$ Male & $7(17.5)$ & & \\
$\quad$ Female & $33(82.5)$ & & \\
BMI & & & \\
$\quad$ Underweight & $7(17.5)$ & $22.0158( \pm 3.46)$ & \\
$\quad$ Normal weight & $25(62.5)$ & & \\
$\quad$ Overweight & $8(20.0)$ & & \\
Education & & & \\
$\quad$ High school & $8(20)$ & & \\
$\quad$ Colleges & $32(80)$ & & \\
Comorbid disease & $12(30.00)$ & \\
$\quad$ Yes & & \\
$\quad$ None & &
\end{tabular}

Omega-3 supplementation has only shown potent efficacy in improving muscle strength in geriatrics. Omega-3 supplementation did not show significant improvement in muscle mass and gait ability in elderly community (Table 2 ).

Table 2. Changes in muscle mass, grip strength, and walking speed before and after treatment

\begin{tabular}{|c|c|c|c|}
\hline \multirow[t]{2}{*}{ Characteristics } & \multicolumn{3}{|l|}{ Treatment } \\
\hline & Before & After & $p$-value* \\
\hline \multicolumn{4}{|l|}{ Muscle mass } \\
\hline Mean (SD) & $38.86( \pm 5.48)$ & $38.87( \pm 5.48)$ & \multirow[t]{2}{*}{0.32} \\
\hline Median (min-max) & $38.2(32.2-54.3)$ & $38.2(32.2-54.3)$ & \\
\hline \multicolumn{4}{|l|}{ Handgrip } \\
\hline Mean (SD) & $25.1( \pm 5.11)$ & $26.2( \pm 5.16)$ & \multirow[t]{2}{*}{0.00} \\
\hline Median (min-max) & $24.0(15-37)$ & $24.5(18-38)$ & \\
\hline \multicolumn{4}{|l|}{ Walking speed } \\
\hline Mean (SD) & $7.06( \pm 1.58)$ & $7.07( \pm 1.24)$ & \multirow[t]{2}{*}{0.53} \\
\hline Median (min-max) & $6.68(5.30-12.00)$ & $6.05(3.87-9.10)$ & \\
\hline
\end{tabular}

\section{Discussion}

Muscle strength is the capacity of the muscles to handle a load [18]. Contraction begins with an 
overlap between actin and myosin filaments. Actin and myosin filaments are arranged in periodic bands called sarcomeres and their repeating sequence forms pipes called fibers. Motor neurons innervate the muscles. The combination of a single motor neuron and muscle fibers innervated by the branches is called a motor unit. Changes in muscle strength due to age can be affected by the number and size of muscles that turn into atrophy and hypoplasia, a decrease in slow and fast motor units and the presence of atrophy in type I and II muscle fibers. This can occur because actin and myosin are essential components in muscle contraction. A decrease in protein synthesis and an increase in muscle protein degradation affect muscle strength in elderly [19].

The study results showed that omega-3 supplementation improved muscle strength in geriatric patients but did not show an increase in muscle mass and the ability to increase walking speed. The effect of omega-3 supplementation has improved handgrip strength, but it takes longer consumption time and a higher dose to achieve maximum results. The improvements that are seen are new to the handheld which is one of the slight motor movements, where there is no need for the intervention of large muscles to move the handgrip, in contrast to walking which requires intervention and the presence of multiple large muscles, which will require longer consumption times and higher doses to achieve significant improvements and changes in muscle strength.

Research by Hutchins-Wiese et al. [20] and Krzyminska-Siemazko et al. [21] states that there is no significant relationship between omega-3 supplementation on muscle mass. In contrast to the research of Smith et al. [22] and Logan and Spriet [23] giving omega-3 $\pm 3 \mathrm{~g}$ for 3-6 months was proven to increase muscle mass, in this study, the dose of omega 3 was only $1.2 \mathrm{~g}$, of course, it is still lower than the above studies which gave up to $3 \mathrm{~g}$. Increasing the dose and duration of consumption and adherence to consumption are vital factors for improving muscle strength and improving functional mobility.

Research by Smith et al. [22] stated that omega-3 supplementation increases muscle strength. This study treated geriatric subjects aged $60-85$ years with omega-3 supplementation as much as $4 \mathrm{~g} /$ day for 9 months. The results of this study indicate an improvement in hand gripping ability and an increase in muscle mass. This study shows that omega-3 supplementation provides optimal results when given sufficiently large doses and long follow-up times.

An in vitro study, Magee et al. [24] have shown that the administration of omega-3 to myoblasts increases the transcription of gene expression in the peroxisome proliferator-activated receptor gamma coactivator 1 alpha pathway so that apoptosis is inhibited and the synthesis of actin and myosin proteins increases. Elevated mitochondrial biogenesis will increase citrate synthase activity by maintaining oxidative capacity (oxidative phosporylation). Then, ROS emission will decrease and it will induce catabolic reactions in musle cells. Increased mitochondrial biogenesis as an energy producer and myosin actin in muscle cells increases muscle strength and is proven through this study [25], [26], [27], [28].

Research by Logan and Spriet [23] states that omega-3 supplementation increases walking speed. The shorter travel time is related to the role of omega-3 acting on the signaling pathway of the mitogenactivated protein kinase cascade during proliferation, the expression of extracellular signal-regulated kinase (ERK) $1 / 2$ will increase and then enter into the nucleus so that the target gene transcription also increases as a result of increased muscle cell proliferation and survival [29], [30], [31]. Furthermore, this pathway inhibits the differentiation of muscle cells to become dominant type I but type II dominance [32]. Type I muscle cells have slow-twitch type fiber, while type II is fast-twitch type, so when type II is dominant, walking speed increases. Type II is a fast fiber with a higher glycolytic potential, low oxidative capacity, and faster response than type I (slow fiber). There is a conversion from type II to type I fibers because of the potential adaptive response. In elderly muscles, the decrease in type I and II fibers results in muscle function changes, especially muscle speed and strength [33], [34]. Based on this study, omega-3 supplementation is beneficial for muscle strength improvement so that clinicians can consider the use of omega-3 in clinical work.

\section{Conclusions}

Omega-3 supplementation improves muscle strength but does not increase muscle mass and physical performance for elderly community.

\section{References}

1. Mangien KK. The frail and institutionalized elder. In: Guccione AA, editor. Geriatric Physical Therapy. $2^{\text {nd }}$ ed. Missouri: Mosby; 2000. p. 445-54.

2. Cherniack EP, Florez HJ, Troen BR. Emerging therapies to treat frailty syndrome in the elderly. Altern Med Rev. 2007;12(3):246-58.

PMid: 18072820

3. Fried LP, Tangen CM, Walston J, Newman AB, Hirsch C, Gottdiener J, et al. Frailty in older adults: Evidence for a phenotype. J Gerontol Med Sci. 2001;56(3):146-56. https://doi. org/10.1093/gerona/56.3.m146 PMid:11253156

4. Woo T, Yu S,Visvanathan R. Systematic literature review on the relationship between biomarkers of sarcopenia and quality of 
life in older people. J Frailty Aging. 2016;5(2):88-99. https://doi. org/10.14283/jfa.2016.93

\section{PMid:27224499}

5. Delmonico MJ, Harris TB, Visser M, Park SW, Conroy MB, Mieyer PV, et al. Longitudinal study of muscle strength, quality and tissue infiltration. J Am Geriatr Soc. 2009;90(6):1579-85. https://doi.org/10.3945/ajcn.2009.28047

PMid:19864405

6. Morley JE. Diabetes, sarcopenia, and frailty. Clin Geriatr Med. 2008;24(3):455-69. https://doi.org/10.1016/j.cger.2008.03.004 PMid: 18672182

7. Cawthon PM, Fox KM,Gandra SR, Delmonico MJ, Chiou CF. Do muscle mass, muscle density, strength, and physical function similarly influence risk of hospitalization in older adults? J Am Geriatr Soc. 2009;57(8):1411-9. https://doi. org/10.1111/j.1532-5415.2009.02366.x

PMid:19682143

8. Janssen I, Shepard DS, Katzmarzyk PT, Roubenoff R. The healthcare costs of sarcopenia in the United States. J Am Geriatr Soc. 2004;52(1):80-5. https://doi. org/10.1111/j.1532-5415.2004.52014.x

PMid:14687319

9. Landi F, Cruz-Jentoft AJ, Liperoti R, Russo A, Giovanni S, Tosato M. Sarcopenia and mortality risk in frail older persons aged 80 years and older: Results from ilsirentestudy. Age Ageing. 2013;42(2):203-9. https://doi.org/10.1093/ageing/afs194 PMid:23321202

10. Bollwein J, Volkert D, Diekmann R, Kaiser MJ, Uter W, Vidal K Nutritional status according to the mini nutritional assessment and frailty in community dwelling older persons:A close relationship. J Nutr Health Aging. 2013;17(4):351-6. https://doi. org/10.1007/s12603-013-0034-7

PMid:23538658

11. Dorner TE, Luger E, Tschinderle J, Stein KV, Haider S, Kapan A. Association between nutritional status and frailty in acute hospitalised elderly patients. J Nutr Health Aging. 2014;18(3):264-9. https://doi.org/10.1007/s12603-013-0406-z PMid:24626753

12. Chevalier S, Saoud F, Gray Donald K, Morais JA. The physical functional capacity of frail elderly persons undergoing ambulatory rehabilitation is related to their nutritional status. $\mathrm{J}$ Nutr Health Aging. 2008;12(10):721-6. https://doi.org/10.1007/ bf03028620

\section{PMid: 19043647}

13. Kaiser MJ, Bauer JM, Ramsch C, Uter W, Guigoz Y Cederholm T. Frequency of malnutrition in older adults: A multinational perspective using the mini nutritional assessment. J Am Geriatr Soc. 2010;58(90):1734-8. https://doi. org/10.1111/j.1532-5415.2010.03016.x

PMid:20863332

14. Wall BT, Gorissen SH, Pennings B, Koopman R, Groun B Virdjik LB. Aging is accompanied by a blunted muscle protein synthetic response to protein ingestion. PLoS One. 2015;10(11):e0140903. https://doi.org/10.1371/journal. pone. 0140903 PMid:26536130

15. Tessier A, Chevalier S. An update on protein, leucine, omega-3 fatty acids, and Vitamin $D$ in the prevention and treatment of sarcopenia and functional decline. Nutrients. 2018;10(8):1099. https://doi.org/10.3390/nu10081099 PMid:30115829

16. Crupi R, Marino A, Cuzzocrea S. N-3 fatty acids: Role in neurogenesis and neuroplasticity. Curr Med Chem. 2013;20(4):2953-63. https://doi.org/10.2174/092986731132099 90140

\section{PMid:23746276}

17. EFSA. Opinion of the scientific panel on dietetic products, nutrition and allergies on a request from the Commission related to labeling reference intake values for $n-3$ and $n-6$ polyunsaturated fatty acids. EFSA J. 2009;1176:1-11. https:// dx.doi.org/10.2903/j.efsa.2009.1176

18. Inouye SK, Studenski S, Tinetti ME, Kuchel GA. Geriatric syndromes: Clinical, research, and policy implications of a core geriatric concept. J Am Geriatr Soc. 2007;55(5):780-91. https:// dx.doi.org/10.1111/j.1532-5415.2007.01156.x PMid:17493201

19. Peterson SJ, Mozer M. Differentiating sarcopenia and cachexia among patients with cancer. Nutr Clin Pract. 2017;32(1):30-9. https://doi.org/10.1177/0884533616680354 PMid:28124947

20. Hutchins-Wiese HL, Kleppinger A, Annis K, Liva E, Keepe CJ, Durhan HA, et al.The impact of supplemental n-3 long chain polyunsaturated fatty acids and dietary antioxidants on physicalperformance in postmenopausal women. J Nutr Health Aging. 2013;17(1):76-80. https://doi.org/10.1007/ s12603-012-0415-3

PMid:23299384

21. Krzyminska-Siemazko $R$, Czepulis $N$, Lewandowicz $M$, Zasadzka E, Suwaska A, Witowski J, et al. The effect of a 12 weeks omega-3 supplementation on body composition, muscle strength and physical performance in elderly individuals with decreased muscle mass. Int J Environ Res Public Health. 2015;12(9):10558-74. https://dx.doi.org/10.3390/ ijerph120910558

PMid:26343698

22. Smith $G I$, Julliand $S$, Reeds $D N$, Sinacore DR, Klein $S$, Mittendofar B, et al. Fish oil-derived n-3 pufa therapy increases muscle mass and function in healthy older adults. Am J Clin Nutr. 2015;102(1):115-22. https://doi.org/10.3945/ajcn.114.105833 PMid:25994567

23. Logan SL, Spriet LL. Omega-3 fatty acid supplementation for 12 weeks increases resting and exercise metabolic rate in healthy community-dwelling older females. PLoS One. 2015;10(12):e0144828. https://doi.org/10.1371/journal. pone. 0144828

PMid:26679702

24. Magee P, Pearson S, Whittingham-Dowd J, Allen J. PPARy as a molecular target of EPA anti-inflammatory activity during $\mathrm{TNF} \alpha$ impaired skeletal muscle cell differentiation. J Nutr Biochem. 2012;23(11):1440-8. https://doi.org/10.1016/j. jnutbio.2011.09.005

PMid:22305406

25. Laplante M, Sabatini D. mTOR signaling at a glance. J Cell Sci. 2009;122(20):3589-94. https://dx.doi.org/10.1242/jcs.051011 PMid:19812304

26. de Roos B, Mavrommatis Y, Brouwer IA. Long-chain n-3 polyunsaturated fatty acids: new insights into mechanisms relating to inflammation and coronary heart disease. $\mathrm{Br} J$ Pharmacol. 2009;158(2):413-28. https://doi. org/10.1111/j.1476-5381.2009.00189.x PMid:19422375

27. Jeromson S, Gallagher IJ, Galloway SDR, Hamilton DL. Omega-3 fatty acids and skeletal muscle health. Mar Drugs. 2015;13(11):6977-7004. https://doi.org/10.3390/md13116977 PMid:26610527

28. Tachtis B, Camera D, Lacham-Kaplan O. Potential roles of n-3 PUFAs during skeletal muscle growth and regeneration. Nutrients. 2018;10(3):309. https://doi.org/10.3390/nu10030309 PMid:29510597

29. Tan A, Sullenbarger B, Prakash R, McDaniel JC. 
Supplementation with eicosapentaenoic acid and docosahexaenoic acid reduces high levels of circulating proinflammatory cytokines in aging adults: A randomized controlled study. Prostaglandins Leukot Essent Fatty Acids. 2018;132:23-9. https://doi.org/10.1016/j. plefa.2018.03.010

PMid:29735019

30. Ewaschuk JB, Almasud A, Mazurak VC. Role of $n-3$ fatty acids in muscle loss and myosteatosis. Appl Physiol Nutr Metab. 2014;39:654-62. https://doi.org/10.1139/apnm-2013-0423 PMid:24869970

31. Gray SR, Mittendorfer B. Fish oil-derived n-3 polyunsaturated fatty acids for the prevention and treatment of sarcopenia. Curr Opin Clin Nutr Metab Care. 2018;21(2):104-9. https://doi. org $/ 10.1097 / \mathrm{mco} .0000000000000441$

PMid:29232264

32. Lalia AZ, Dasari S, Robinson MM, Abid H, Horse DM, Klaus KA, et al. Influence of omega- 3 fatty acids on skeletal muscle protein metabolism and mitochondrial bioenergetics in older adults. Aging (Albany NY). 2017;9(4):1096-129. https://doi. org/10.18632/aging.101210

PMid:28379838

33. Mozaffarian D, Lemaitre RN, King IB, Song $X$, Huang $H$, Sack FM, et al. Plasma phospholipid long chain omega-3 fatty acids and total and cause-specific mortality inolder adults: A cohort study. Ann Intern Med. 2013;158(7):515-25. https:// dx.doi.org/10.7326/0003-4819-158-7-201304020-00003 PMid:23546563

34. Reinders I, Song X, Visser M, Eiriksdottir G, Gudnason V, Sigurdsson $\mathrm{S}$, et al. Plasma phospholipid pufas are associated with greater muscle and knee extension strength but not with changes in muscle parameters in older adults. J Nutr. 2015;145(1):105-12. https://doi.org/10.3945/jn.114.200337

PMid:25355842 